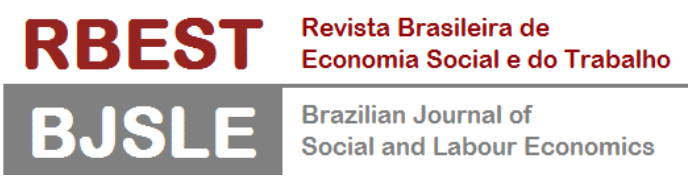

https://doi.org/10.20396/rbest.v2i..14341

DOSSIER: INEQUALITY

\title{
The effects of the Brazilian recession on wage inequality between men and women
}

\author{
Carolina Troncoso Baltar* \\ Lilian Nogueira Rolim** \\ Eugenia Troncoso Leone***
}

\begin{abstract}
The Brazilian economy entered a deep recession in 2014, when the country's GDP decreased, with negative consequences for the labour market. The aim of this paper is to analyse the effect of this recession on the country's wage inequality, taking into account sex differences. The paper classifies employees in different groups considering occupational groups and the sectors of activities these workers belong to in order to verify who are the employees better inserted in the labour market and the ones who are in a more vulnerable situation, separating them by sex. The results show a high asymmetry and dispersion of wage distribution in Brazil. The economic recession of 2015-2016 reduced the country's income inequality and the differences between men and women, because the share of workers with lower wages increased. However, wage differences in favour of men are still high, especially in occupations of high income and higher education requirements.
\end{abstract}

Keywords: Income distribution; Gender; Labour market; Segregation; Discrimination. JEL: J01, J16, J31, J71.

* Universidade Estadual de Campinas (Unicamp), Brazil.

Orcid: http://orcid.org/0000-0002-3317-8169

E-mail: cbaltar@unicamp.br

** PhD Program in Economics, Unicamp, Brazil.

Orcid: http://orcid.org/0000-0002-9880-2823

E-mail: lilian.rolim@gmail.com

*** Universidade Estadual de Campinas (Unicamp), Brazil.

Orcid: http://orcid.org/0000-0001-8334-6194

E-mail: eleone@unicamp.br

\section{$(\mathrm{Cc}) \mathrm{BY}-\mathrm{NC}-\mathrm{SA}$}

Acknowledgments: Eugenia Troncoso Leone and Lilian Nogueira Rolim acknowledge research funding provided by the Brazilian National Council for Scientific and Technological Development (CNPq). Preliminary versions of the paper were presented at the 16th World Congress of Social Economics (USA), 15th International Conference Developments in Economic Theory and Policy (Spain) and XII Global Labour University Conference (Brazil). We thank the participants for their comments, which have helped to improve the paper. 


\section{Os efeitos da recessão brasileira sobre a desigualdade salarial entre homens e mulheres}

\section{Resumo}

A economia brasileira entrou numa recessão profunda em 2014, quando o PIB do país começou a reduzir, com reflexos negativos para o mercado de trabalho. O objetivo deste artigo é analisar o efeito dessa recessão sobre a desigualdade salarial no país, levando em consideração as diferenças por sexo. O artigo classifica os trabalhadores em diferentes grupos considerando os grupos ocupacionais e os setores de atividades a que pertencem para verificar quem são os trabalhadores mais bem inseridos no mercado de trabalho e os que se encontram em situação de maior vulnerabilidade, separando-os por sexo. Os resultados mostram uma elevada assimetria e dispersão da distribuição dos salários no Brasil. A recessão econômica de 2015-2016 reduziu a desigualdade de renda no país e as diferenças entre homens e mulheres, pois aumentou a proporção de trabalhadores com salários mais baixos. No entanto, as diferenças salariais a favor dos homens ainda são altas, principalmente em ocupações de alta renda e com requisitos de educação superior.

Palavras-chave: Distribuição de renda; Gênero; Mercado de trabalho; Segregação; Discriminação.

\section{Los efectos de la recesión brasilera sobre la desigualdad salarial entre hombres y mujeres}

\section{Resumen}

La economía brasilera entró en un período de recesión profunda en el 2014, cuando el PIB del país comenzó a reducirse con consecuencias negativas para el mercado de trabajo. El objetivo del artículo es analizar los efectos de esta recesión sobre la desigualdad salarial en el Brasil, teniendo en cuenta las diferencias por sexo. El artículo clasifica los trabajadores en diferentes grupos considerando los grupos ocupaciones y los sectores de actividad a la que pertenecen, para verificar quienes son los trabajadores que están mejor ubicados en el mercado laboral y los que se encuentran en situación de mayor vulnerabilidad, separándolos por sexo. Los resultados muestran una elevada asimetría y dispersión de la distribución de salarios en Brasil. La recesión económica de 2015-2016 redujo la desigualdad de ingresos en el país y la diferencia entre hombres y mujeres a medida que aumentó la proporción de los trabajadores con salarios más bajos. Sin embargo, las diferencias salariales a favor de los hombres aún son altas, principalmente en ocupaciones de alto ingreso y con educación superior.

Palabras clave: Distribución de ingreso; Género; Mercado de trabajo; Segregación; Discriminación.

\section{Les effets de la récession brésilienne sur les inégalités salariales entre hommes et femmes}

\section{Résumé}

L'économie brésilienne est confrontée à une profonde récession en 2014, lorsque le PIB du pays a diminué, avec des conséquences négatives pour le marché du travail. L'objectif de cet article est d'analyser l'effet de cette récession sur l'inégalité salariale du pays, en tenant compte des différences entre les sexes. Le document classe les employés dans différents groupes en tenant compte des groupes professionnels et des secteurs d'activités auxquels ces travailleurs appartiennent pour vérifier qui sont les employés les mieux insérés sur le marché du travail et ceux qui sont dans une situation plus vulnérable, en les séparant par sexe. Les résultats montrent une asymétrie et une dispersion élevées de la répartition des salaires au Brésil. La récession économique de 2015-2016 a réduit les inégalités de revenus dans le pays et les différences entre les hommes et les femmes, car la proportion de travailleurs à bas salaires a augmenté. Cependant, les écarts de salaire en faveur des hommes sont encore élevés, en particulier dans les professions à revenu élevé et exigeant une formation supérieure.

Mots clés: La répartition des revenus; Genre; Marché du travail; Ségrégation; La discrimination. 


\section{Introduction}

The Brazilian economy experienced a period of economic growth with social inclusion between 2004 and 2013, which led to an increase in the income of the poorest households. However, the economy faced a deep recession from the second quarter of 2014 to the first quarter of 2017, when its real GDP decreased considerably, with negative consequences for the labour market.

Baltar and Rolim (2018) showed that the recession decreased the wage dispersion, reducing the country's wage inequality. ${ }^{1}$ However, as this took place in a context of negative GDP growth rates, it did not correspond to an effective improvement in the labour market. The reduced wage dispersion was a consequence of an increase in the number of workers with lower wages at the same time as unemployment increased.

The aim of this paper is to further analyse the effects of the recent Brazilian recession on the country's wage inequality, taking into account sex differences. In particular, we investigate whether such reduction in wage inequality for those who remained employed during the recession was related to changes in wage inequality between men and women. In fact, the recession reduced the employment and raised considerably the number of unemployed people, but the population in the active economy remained high, especially due to women. During the recession and the stagnation period, women's participation in the economic activity continued to increase slowly. Therefore, we analyse the consequences of women's participation rates for the labour market and wage inequality.

The analysis compares the third quarter of 2014, which represents the structure of the labour market when economic activity is high, with the third quarter of 2016, which represents the recession period, using data from the quarterly National Household Sample Survey (PNADC). Following Baltar and Rolim (2018), the third quarter of each year is considered because it characterises better the Brazilian economic structure and its labour market compared with the other quarters of the year, in which seasonal effects are relatively stronger. ${ }^{2}$ After presenting an overall analysis, the labour market is analysed through the methodology of Baltar and Rolim (2018), which classifies workers in different categories taking into account occupational groups and the sectors of activities in which these workers are inserted. The objective of this analysis is to verify who are the employees better inserted in

\footnotetext{
${ }^{1}$ Hoffmann et al. (2018) show that the labour income inequality increased considerably in 2015 and 2016 when the unemployed is considered in the analysis.

2 The Brazilian Institute for Geography and Statistics (IBGE) uses information from September to build their annual household surveys because this month better characterises the structure of the economy.
} 
the labour market and the ones who are in a more vulnerable situation, apart from considering differences by sex.

The occupational segregation among employees is also analysed as it explains part of the wage inequality, together with the discrimination within the occupations (England, 2010). Such segregation means that women and men exert different types of activities and are in different hierarchies within the occupations. This reflects the current sexual division of labour, which appears in the different occupations, working conditions and household responsibilities between men and women in our society (Hirata, 2017). Consequently, the sexual division of labour keeps women in activities that are the least valued socially and that offer lower wages (Benería, Berik, \& Floro, 2016).

The paper is organised in six sections including this introduction. Section 1 discusses the improvements in women's working conditions that occurred in the period of economic growth with social inclusion in the 2000s and beginning of the 2010s. Section 2 presents the evolution of the participation in the economic activity comparing 2014 with 2016, which refers to the recession. Section 3 presents the wage inequality between occupied men and women in Brazil and how it changed with the recession. Section 4 analyses the evolution of the wage inequality between men and women in the labour market. Finally, the last section presents some concluding remarks.

\section{Improvements in women's working conditions in the 2000s and 2010s}

After decades of continuous growth of women's participation in the labour market, they still face expressive difficulties in having a better-quality insertion in the economic activity. Therefore, it is still a challenge for women to have diverse possibilities of accessing job positions, employment stability, union protection, social security and equal wages to those of men, which would overcome the stigma of being a secondary source of the household income (Abramo, 2004; Arriagada, 2006; Bruschini, 2000; among others).

Women's participation in the financial provision of the household has increased with their paid work. However, the equivalent has not occurred in terms of a better distribution of the household responsibilities and housework between men and women (Hirata, 2017). Indeed, women's higher participation in the labour market does not correspond to a less intense housework journey (Dedecca, 2004). The overburden of these household activities on women has a direct effect on their participation in the economic activity. In Brazil, despite men working more hours in productive activities, their overall working hours are lower than those of women, because women spend considerably more hours in reproductive activities roles (for example, homework and caring of the child and elderly people) than men (Pinheiro, 2016; Gibb \& Oliveira, 2015). 
Consequently, women are obliged to adapt their paid work to their household responsibilities, ${ }^{3}$ which puts them in disadvantage to men when it comes to their economic activity (Montali, 2017). Such disadvantage appears, mainly, in their activity condition (lower participation and higher unemployment rates than men), high participation in the worst informal situations (non-paid work and domestic employment without a labour contract) and in the worse paid formal employments.

Brazil has always been characterised by its high inequality, which expresses itself also in the income gap between men and women in the labour market. Women's income levels are lower than those of men regardless of the education level and/or the position in the occupation. ${ }^{4}$ However, since 2007 the minimum wage adjustment rule ${ }^{5}$ had a positive effect for women who earned up to one minimum wage, increasing their income and reducing their gap with respect to men. The domestic employees benefited considerably from such rule. Still, the gap between women's and men's incomes remained wide (Teixeira, 2013).

These differences are part of a context of tremendous income inequality, in which the education level differences stand out, particularly with respect to the high earnings in the higher education level with respect to the other education levels. Yet, it is exactly in the higher education level, in which women have the highest participation, that the more expressive differences between men's and women's incomes occur. Therefore, as the education level increases, the difference between men and women's average incomes increases (Portilho, 2020). This reflects the persistence of women and men in certain fields so that women's participation is still more expressive in the less prestigious and worse remunerated careers.

Indeed, among workers with a higher education level, the characteristics of these workers in terms of position in the occupation is different between men and women. Among men, the participation of self-employed work (employers and own-account workers) is larger and, in these types of occupations, the income differences by sex are quite high. These differences are even larger in the formal employment, exactly where women's participation is higher, as in the management positions, in the occupations which require college education level, in the technical positions and in administrative services. Thus, men's participation in the higher levels of the position's hierarchy prevails.

\footnotetext{
3 Household responsibilities are the activities mainly carried out by women related to the reproduction of the labour force (that is, activities devoted to the well-being of others that includes daily activities as cooking, washing clothes and also the caring for child and elderly people).

4 See Leone and Baltar (2006) and Guedes and Alves (2004). According to Beltrão and Alves (2009), women's education achievements have occurred in a progressive manner and the proportion of younger women who complete college education is almost twice of that of men. However, these achievements have not been followed by similar achievements in the labour market.

5 This rule was established in 2011, renewed in 2015 and valid until 2019. It states that the nominal minimum wage is adjusted every year according to the inflation rate of the previous year and the GDP growth from two years before.
} 
The resumption of the Brazilian labour market between 2004 and 2013 was one of the main factors for the relative improvement in the Brazilian population socioeconomic condition (Leone, 2020). The improved performance of the labour market was expressed in the reduction of the unemployment rate, in the increase of the participation of employees, in the increase of the rate of labour contract formalisation in facilities ${ }^{6}$ and in the increase of the labour income level, which increased the purchasing power of the occupied people's income. The strong expansion of formal employment and the expressive increase in income led to higher household income levels, which, together with the larger credit demand and supply, raised consumption (Leone, 2017).

These results were the most striking aspects of the resumption of the labour market performance and they brought important improvements to millions of male and female workers. According to the document by ONU Mulheres (2016), based on the yearly National Household Sample Survey (PNAD), between 2004 and 2014, more than 15 million of workers were incorporated in the labour market, with 49.5\% of them being women. Between 2003 and 2014, based on the Annual Social Information Report (RAIS), more than 9 million women were hired in registered occupations, consequently having more access to the social security system. During this period, there was an important increase in the Brazilian labour formalisation. Informal paid domestic work decreased from $12.7 \%$ to $9.6 \%$ and the percentage of women engaged in activities for own consumption or in non-paid work decreased from $14.8 \%$ to $9.6 \%$ (ONU Mulheres, 2016, p.18).

The better performance of the labour market was followed by some measures that benefited women specifically. In 2013, through the Constitutional Amendment Number 72, domestic employees' labour rights were made equivalent to those of other employees, giving them the same benefits (Biavaschi, 2017). Such regulation had a strong impact on women because only $5 \%$ of those in this type of employment were men (Hirata, 2017).

The public policies played an important role in the period of economic growth in Brazil by increasing the social investment in a way that improved equality and social inclusion. It is important to mention the Bolsa Família Program, a conditioned cash transfer program created in 2013, which had a positive impact on women and helped to reduce social inequalities. In $2014,93 \%$ of the households that received cash transfers from the Program were headed by women, representing around 13 million of households. ${ }^{7}$

\footnotetext{
${ }^{6}$ There was an increase in the proportion of contracts under the Brazilian labour laws in the total of contracts in the facilities.

7 The Bolsa Família Program prioritises transfers to women and conditions them to the fulfillment of some criteria such as a satisfactory children school attendance and the health monitoring of the children and mother. Therefore, despite providing women with some income, the program crystallises the household model in which women are responsible for the reproductive activities (Mariano \& Carloto, 2009).
} 
The actions by the Secretariat for Women Policies also had a meaningful role in this process, promoting better working conditions for women and discharging them from the housework and household responsibilities to facilitate their insertion in the labour market. One of these policies has been the expansion of childcare services, through the Brasil Carinhoso, an initiative by the Program Brazil Without Extreme Poverty (Brasil sem Miséria), which was established in 2011 and whose actions are linked to other policies that aim to overcome poverty, improve the access to basic services and reduce the social inequalities (Bandeira \& Preturlam, 2016). The expansion of the number of day-care facilities is a key policy to increase women's participation in the labour market and promote more gender equality. In 2001, only $10.6 \%$ of the children between 0 to 3 years old were enrolled in daycare. In 2013, this number increased to $23.2 \%$ of those in this age range (ONU Mulheres, 2016).

These policies had the aim of promoting a more symmetric household model, that is, women and men working in a more egalitarian way in both spaces: the paid work and the household responsibilities. The economic growth with social inclusion and the improvements in the labour market between 2004 and 2013 allowed women to enhance their participation in the economic activity in a qualitative manner (Leone, 2017). The improvements have been expressive, but the female disadvantages are still in place.

\section{Brazilian recession and participation by sex}

The Brazilian economy faced a deep recession between 2015 and 2016, which led to a $7.2 \%$ reduction of its GDP in two years and to an increase of its unemployment rate from $6.8 \%$ in the third quarter of 2014 to $11.8 \%$ in the third quarter of 2016 . This scenario had negative consequences for the labour market and altered women and men's participation in this market.

GDP growth had decelerated since 2011 and stopped increasing in 2014 due mainly to the decrease in investment and exports. Consumption deceleration was less intense and the labour market kept improving until 2014. Investment and consumption had a sharp decrease in 2015, reducing the Brazilian GDP in 2015 and 2016. Consequently, manufacturing production and civil construction were negatively affected as well as trade and transport. The decrease in GDP and the increase in unemployment affected household income and consumption, mainly of durable goods (Teixeira, 2019).

In 2014, the Brazilian population in active age was of 162.4 million and the active population was of 99 million, providing a participation rate of $60.9 \%$ (Table 1 ). Women represented $52.3 \%$ of the population in active age and $43.3 \%$ of the active population. So, the participation rate for women was $50.4 \%$, much lower than the participation rate for men, 
which was $72.4 \%$ in the same period. Yet, these figures reflect the progressively higher participation rate of women in the labour market since the 1990s, while that of men reduced in the same period (Montali, 2017).

Table 1. National labour market data. Brazil: 2014, 2016.

\begin{tabular}{|c|c|c|c|c|c|c|}
\hline & \multicolumn{3}{|c|}{2014 Q3 } & \multicolumn{3}{|c|}{2016 Q3 } \\
\hline & Men & Women & Total & Men & Women & Total \\
\hline Population in active age & 77.5 & 84.9 & 162.4 & 79.7 & 86.8 & 166.5 \\
\hline Active population & 56.1 & 42.9 & 98.9 & 57.4 & 44.5 & 101.9 \\
\hline - Employed & 52.9 & 39.3 & 92.3 & 51.4 & 38.5 & 89.8 \\
\hline - Unemployed & 3.2 & 3.5 & 6.7 & 6.0 & 6.0 & 12.0 \\
\hline Participation rate (\%) & 72.4 & 50.4 & 60.9 & 72.0 & 51.3 & 61.2 \\
\hline Unemployment rate (\%) & 5.7 & 8.2 & 6.8 & 10.5 & 13.5 & 11.8 \\
\hline Employment rate (\%) & 68.3 & 46.3 & 56.8 & 64.4 & 44.3 & 54.0 \\
\hline
\end{tabular}

Source: IBGE - PNADC. Prepared by the authors.

The Brazilian employment rate was $56.8 \%$ and the unemployment rate was $6.8 \%$ in 2014 (Table 1). According to Baltar and Leone (2015), the unemployment rate started decreasing from 2004 onwards due to a better economic activity. Within the active population, women represented $42.6 \%$ of those employed and $52.7 \%$ of those unemployed in 2014 . Therefore, the participation of women in the unemployed population was much higher than their participation in the active population.

Table 1 shows that the number of employed people reduced by $2.6 \%$ between 2014 and 2016, which is a smaller reduction than that of the Brazilian GDP during the same period (the Brazilian GDP of 2016 was $7.2 \%$ smaller than the one of 2014). However, the unemployment rate increased considerably (from $6.8 \%$ in 2014 to $11.8 \%$ in 2016) as the participation rate increased in the period, indicating that the active population increased more than the population in active age. The active population increased more for women than for men, so the increase in the overall participation rate was due to the increase of the participation rate of women, as men's participation rate decreased in the period.

With the recession, the number of unemployed men increased faster than the number of unemployed women, reducing the relative differences between unemployed women and men in the Brazilian labour market. In terms of unemployment rate, the difference between men and women was also reduced, considering that in 2014 women's unemployment rate was 43.9\% higher than men's unemployment rate, and in 2016 this difference reduced to $28,6 \%$. 
Such pattern suggests, as already pointed, that during the recession, women's participation in the labour market helped to avoid a stronger reduction in the household income. This means that, during the recession, with increasing men's unemployment, women had to face an increase in their productive responsibilities together with their previous reproductive responsibilities. Nevertheless, the extent of the recession was such that the number of employed women decreased, and the number of unemployed women increased by $70.4 \%$ (the unemployment rate for women increased from $8.2 \%$ in 2014 to $13.5 \%$ in 2016).

Therefore, the recession reverted the improvements observed in the labour market since 2004, when the recovery of the Brazilian economy led to a progressive decrease of the unemployment rate. With the deceleration of the economy since 2010 , it was still possible to sustain low unemployment rates because the participation rate had been decreasing since the 2000s. Such decrease was largely attributed to the fact that the young population delayed their entry into the labour market (Baltar \& Leone, 2015), which was linked to the extension of public policies since 2003, in particular those that stimulated young people to achieve higher levels of education (Santos \& Gimenez, 2015). Still, the participation rate of young people (aged between 14 to 24 years old) is still high in Brazil and young men and women face higher unemployment rates (Table 2 ).

Table 2. Participation rate, unemployment rate and employment rate by age and sex. Brazil: 2014, 2016.

\begin{tabular}{|c|c|c|c|c|c|c|c|c|c|}
\hline & \multicolumn{3}{|c|}{ Participation rate (\%) } & \multicolumn{3}{|c|}{ Unemployment rate (\%) } & \multicolumn{3}{|c|}{ Employment rate (\%) } \\
\hline & Men & Women & Total & Men & Women & Total & Men & Women & Total \\
\hline \multicolumn{10}{|c|}{2014 Q3 } \\
\hline 14 to 24 & 56.0 & 42.2 & 49.2 & 13.7 & 19.6 & 16.2 & 48.4 & 33.9 & 41.2 \\
\hline 25 to 54 & 90.7 & 67.5 & 78.6 & 4.2 & 6.4 & 5.1 & 86.9 & 63.2 & 74.6 \\
\hline 55 or more & 45.3 & 21.1 & 31.9 & 2.3 & 2.1 & 2.2 & 44.3 & 20.6 & 31.2 \\
\hline Total & 72.4 & 50.4 & 60.9 & 5.7 & 8.2 & 6.8 & 68.3 & 46.3 & 56.8 \\
\hline \multicolumn{10}{|c|}{2016 Q3 } \\
\hline 14 to 24 & 55.0 & 43.1 & 49.2 & 24.5 & 32.0 & 27.7 & 41.5 & 29.3 & 35.5 \\
\hline 25 to 54 & 90.6 & 68.8 & 79.3 & 7.9 & 10.6 & 9.1 & 83.4 & 61.6 & 72.1 \\
\hline 55 or more & 45.3 & 21.5 & 32.1 & 5.2 & 3.8 & 4.7 & 43.0 & 20.6 & 30.6 \\
\hline Total & 72.0 & 51.3 & 61.2 & 10.5 & 13.5 & 11.8 & 64.4 & 44.3 & 54.0 \\
\hline
\end{tabular}

Source: IBGE - PNADC. Prepared by the authors.

With the recession, the unemployment rate increased considerably for all age groups and the pattern of a very high unemployment rate for young people remained. This very high increase in the unemployment rate for all age groups took place for both men and women, although men's rates increased faster. 
Within the occupied population, there are also different forms of participation in the economic activity specific to each sex, especially in terms of the possibilities of having a well-structured job position. This is linked to the segregation existent in the labour market, which will be further discussed in section 3. Indeed, while there is a low participation of employees ${ }^{8}$ in the total of occupations $\left(69.8 \%\right.$ in 2014), ${ }^{9}$ it is more relevant for women than men (Table 3). This reflects a heritage of the labour market in which the low-skilled adult men were expelled from the labour market (Baltar and Leone, 2015) as well as a new phenomenon in which occupied workers appear as own-account workers in order to gain flexibility (Baltar and Rolim, 2018). On the other hand, formal employment is more relevant for men than for women (Table 3).

Table 3. Proportion of employees and formalisation rate by age and sex. Brazil: 2014, 2016.

\begin{tabular}{|c|c|c|c|c|c|c|}
\hline & \multicolumn{3}{|c|}{ Employees / Occupied } & \multicolumn{3}{|c|}{ Formal / Employees } \\
\hline & Men & Women & Total & Men & Women & Total \\
\hline \multicolumn{7}{|c|}{2014 Q3 } \\
\hline 14 to 24 & 79.3 & 86.0 & 82.0 & 63.1 & 63.0 & 63.1 \\
\hline 25 to 54 & 66.7 & 76.4 & 71.0 & 81.1 & 73.9 & 77.7 \\
\hline 55 or more & 44.0 & 56.4 & 48.5 & 74.7 & 63.7 & 70.0 \\
\hline Total & 65.5 & 75.7 & 69.8 & 76.8 & 71.1 & 74.2 \\
\hline \multicolumn{7}{|c|}{2016 Q3 } \\
\hline 14 to 24 & 78.3 & 83.4 & 80.4 & 61.5 & 63.1 & 62.1 \\
\hline 25 to 54 & 65.5 & 76.1 & 70.2 & 79.0 & 73.8 & 76.5 \\
\hline 55 or more & 44.2 & 59.0 & 49.7 & 73.3 & 60.9 & 67.8 \\
\hline Total & 64.2 & 75.0 & 68.8 & 75.2 & 70.9 & 73.2 \\
\hline
\end{tabular}

Source: IBGE - PNADC. Prepared by the authors.

The recession led to an overall deterioration of the labour market, but it did not alter the pattern of a higher participation of employees for occupied women and a higher participation of formal employment for male employees. Still, during the recession, there was a reduction of employees and formal employment for both sexes (Table 3 ), but there was a smaller reduction of employees' participation and formalisation rates for women than for men. This suggests that, with the recession, less women were excluded from paid employment and from formal employment compared with men, decreasing the relative disadvantage of women. However, the consequences of the recession were negative for all workers. Besides that, it is

\footnotetext{
8 The Labour Force Survey defines an employee as an individual who works for a public or private employer and who in return receives compensation in the form of wages, salaries, fees, gratuities, payment by results or payment in kind. Professional military staff are also included.

${ }^{9}$ If compared to the European countries (EU-28), for instance, where employees were on average $85 \%$ of the occupied population in 2016, according to the Eurostat.
} 
important to mention the negative consequences of the labour reform and social security for workers, especially for women due to the particularities of their jobs.

\section{Wage inequality between men and women in Brazil}

These changes in the participation in the economic activity after the recession had important effects on the wage distribution between men and women. Considering only employed people with positive income, some indicators suggest a reduction of wage inequality in the period (Table 4), as already pointed out by Baltar and Rolim (2018). For the occupied population, the standard deviation decreased more than the average income, which, in turn, decreased more than the median income, leading to a lower relation between the average and median incomes, as well as to a lower coefficient of variation. ${ }^{10}$ On the other hand, the average income of the $90^{\text {th }}$ percentile increased more than that of the $10^{\text {th }}$ percentile (respectively $10.9 \%$ and $7.0 \%$ in real terms), so the ratio of the $90^{\text {th }}$ to the $10^{\text {th }}$ percentiles increased (from 8.57 to 8.89$) \cdot{ }^{11}$

Table 4. Average monthly incomes (main work). Brazil: 2014, 2016.

( $R \$$ of $2014 \mathrm{Q} 3$ )

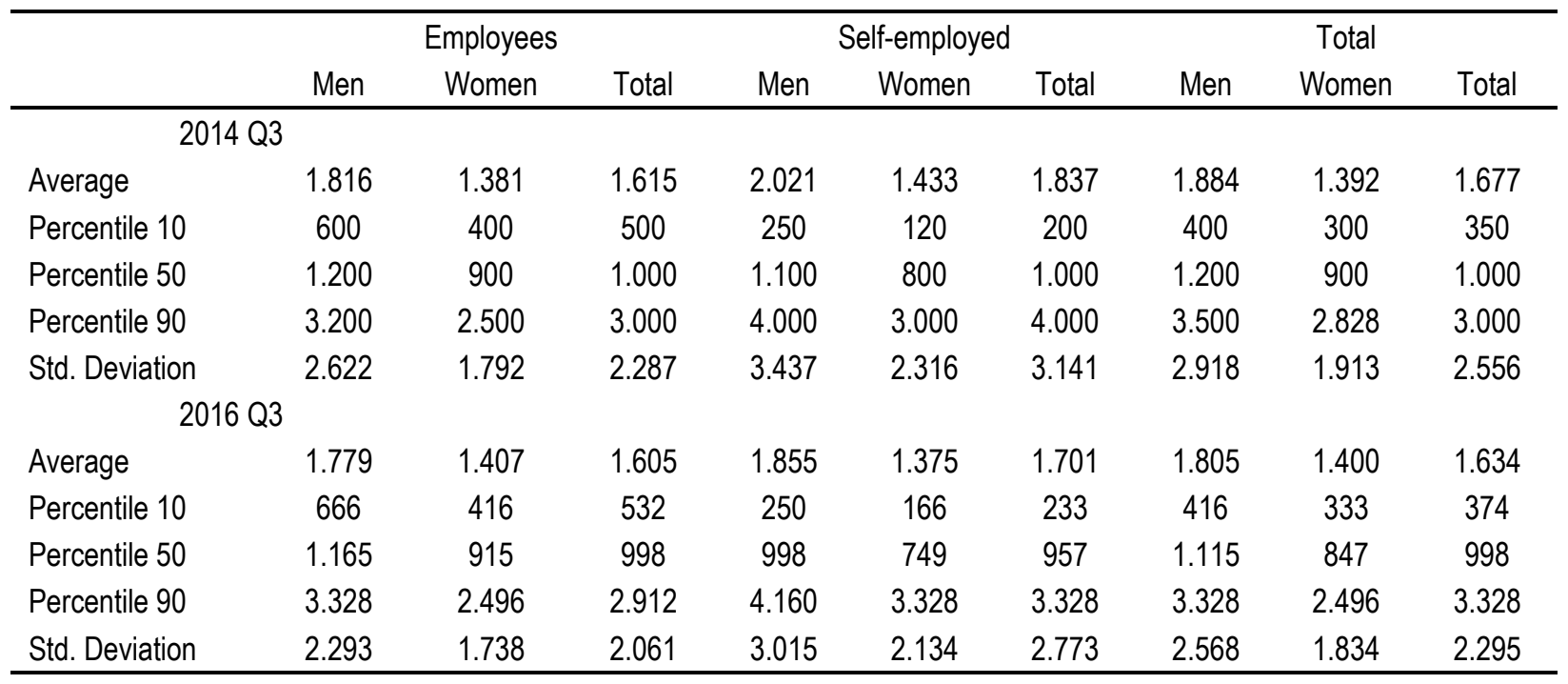

Source: IBGE - PNADC. Prepared by the authors.

Note: Deflated data following recommendations made by Corseuil and Foguel (2002).

10 This was not observed in terms of sex income inequality. For both men and women, there was a lower dispersion but a higher ratio between the average and median incomes.

11 This is also not observed in the comparison of the $90^{\text {th }}$ and $10^{\text {th }}$ percentiles of each sex, as there was an increase in the income of the $10^{\text {th }}$ percentiles and a decrease in the income of the $90^{\text {th }}$ percentile. Thus, it was the wealthier population of the $90^{\text {th }}$ percentiles of each sex that had an increase in their incomes. 
The lower wage inequality was also observed in the comparison between men and women, as the changes in the participation of each sex in the economic activity materialised as a decrease in their relative differences. Indeed, the relation between women's average income and men's average income increased from $74.1 \%$ to $77.5 \%$ because men's average income decreased $4.2 \%$ (from $R \$ 1,884$ to $R \$ 1,805$ ) and women's average income increased $0.6 \%$ (from $R \$ 1,392$ to $R \$ 1,400$ ), in real terms ( $R \$$ of $2014 Q 3$ ), as shown in Table 4 . As the relation between women's and men's median incomes stayed roughly the same $(75.2 \%$ in 2014 and $75.8 \%$ in 2016), this suggests that it was the better position of above-median men that decreased relatively to above-median women.

Thus, the structure of the participation in the economic activity in 2014 showed a lower and a more precarious participation of women than men, expressed by the lower formalisation rates and lower wage income. The recession did not alter these patterns, but it reduced the relatively better position of men, both in terms of the job opportunities and the average incomes, probably because of the effect of the recession on men's participation. The next section explores in more detail how this occurred in the labour market.

\section{Labour market and wage inequality between men and women}

As the labour market represents at least $70 \%$ of the occupied population (Table 3), wage inequality and segregation are further analysed in this group. In order to evaluate the wage distribution by sex within the Brazilian labour market, we use the methodology applied by Baltar and Rolim (2018), which categorises the economic activities in the labour market according to the required level of qualification and the degree of business organisation. These two criteria condition the level of unionisation and the workers' remuneration levels in the different economic activities.

Based on this methodology, we split the workers into nine different categories going from category $A$, which is linked to more complex types of activities (which require a higher level of education and where the highest levels of remuneration are found), to category $\mathrm{I}$, in which the remuneration and qualification requirement levels are the lowest. ${ }^{12}$ Table 5 presents the occupational groups and activity sectors that belong to each category.

The consideration of these categories to evaluate wage inequality between men and women provides elements to verify the existence of segregation and possible discrimination in the Brazilian labour market. Segregation in the labour market means that there is an asymmetry in the hiring of workers by firms based on certain characteristics, such as sex, skin colour, nationality and professional qualification. The consequence is the

\footnotetext{
12 See Baltar and Rolim (2018) for a detailed explanation of each category.
} 
concentration of workers in different segments, creating occupational ghettos. For instance, occupational sex segregation occurs when the proportion of men and women in activity sectors are different from the proportion observed in the population as a whole (Oliveira, 1998). In this case, the occupational segregation is classified as a horizontal segregation, while the vertical segregation occurs when men and women are employed in a same occupation but in different hierarchical levels (Teixeira, 2017).

Table 5. Categories' occupational groups and activity sectors.

\begin{tabular}{|c|l|}
\hline Category & \multicolumn{1}{c|}{ Occupational groups and activity sectors } \\
\hline A & $\begin{array}{l}\text { Professionals of Science and Arts in the industry and construction; Directors and Managers } \\
\text { in services for firms. }\end{array}$ \\
\hline B & $\begin{array}{l}\text { Directors and Managers in the industry, transport, public administration and construction; } \\
\text { Professionals of Science and Arts in the transportation, public administration and business } \\
\text { services. }\end{array}$ \\
\hline C & $\begin{array}{l}\text { Directors and managers in the education, health and social services; Professionals of Science } \\
\text { and Arts in trade; Members of the armed forces in the public administration. }\end{array}$ \\
\hline D & $\begin{array}{l}\text { Professionals of the Sciences and Arts in the agricultural sector and education, health and } \\
\text { social services; Directors and managers in trade and other services; Technician" in the public } \\
\text { administration and transport. }\end{array}$ \\
\hline E & $\begin{array}{l}\text { Professionals of the Sciences and Arts in the housing and food sector; Technician of average } \\
\text { level in the industry; occupations related to the public administration. }\end{array}$ \\
\hline F & $\begin{array}{l}\text { Skilled workers in the transportation sector; Middle level occupational group in services for } \\
\text { business, housing and food, construction and agricultural sector; Directors and managers in } \\
\text { the housing and food sector. }\end{array}$ \\
\hline G & $\begin{array}{l}\text { Technician of medium level in commerce and education, health and social services; Operators } \\
\text { of installations and machines in the transport, construction, public administration, services to } \\
\text { companies and domestic services; Construction workers; Administrative support working the } \\
\text { transport, construction and industry. }\end{array}$ \\
\hline H & $\begin{array}{l}\text { Operators of installations and machines in the trade sector and industry; Service workers in } \\
\text { the transport, business services, trade and education, health and social services; } \\
\text { Administrative support work for education, health and social services, trade and other services }\end{array}$ \\
\hline $\begin{array}{l}\text { Basic occupations in services provided to enterprises, education, health and social services, } \\
\text { public administration, construction and domestic services; Skilled labour of agriculture and } \\
\text { Service workers for domestic service. }\end{array}$ \\
\hline
\end{tabular}

According to Emerek et al. (2003), sex segregation suggests a discrimination against women in the labour market. Discrimination refers to a situation in which equally productive workers with the same qualification are evaluated differently in the labour market due to non-productive attributes, such as skin colour or sex. In this case, the employer decides not to hire this person or they hire her only paying lower wages (Ribeiro \& Araujo, 2016). Both sex segregation and discrimination affect the quality of women's work when they have skills for activities that they are not able to develop, apart from the fact that some activities end up 
consolidated as women's activities, which in general are activities with lower pay (Emerek et al., 2003).

Baltar and Rolim (2018) showed the deep Brazilian wage inequality, with a high concentration of workers in activities that pay low wages. The authors show that $72.5 \%$ of Brazilian workers in 2014 had an income lower than the average income, and only $27.5 \%$ had an income higher than the average. Besides that, the authors also show that more than half of the Brazilian workers' occupations are concentrated in activities with low remuneration and that require low qualification. Table 6 shows that this pattern occurs for both men and women, as $74.3 \%$ of working men and $72.1 \%$ of working women are classified in the categories $\mathrm{G}, \mathrm{H}$, and I.

Table 6. Income according to sex and categories. Brazil: 2014, 2016.

\begin{tabular}{lcccccccccc}
\hline \multicolumn{1}{c}{ 2014 } & $\mathrm{A}$ & $\mathrm{B}$ & $\mathrm{C}$ & $\mathrm{D}$ & $\mathrm{E}$ & $\mathrm{F}$ & $\mathrm{G}$ & $\mathrm{H}$ & $\mathrm{I}$ & Total \\
\hline \% men & 3.0 & 3.8 & 2.5 & 5.9 & 3.2 & 7.3 & 27.1 & 30.1 & 17.1 & 100.0 \\
\% women & 2.0 & 4.9 & 1.1 & 13.2 & 1.2 & 5.4 & 14.6 & 29.0 & 28.5 & 100.0 \\
\% women in the category & 36.2 & 52.7 & 27.5 & 65.7 & 24.7 & 39.0 & 31.7 & 45.2 & 58.9 & 46.2 \\
Ratio (average income of I = 100) & 695.5 & 550.5 & 427.7 & 373.5 & 304.3 & 264.9 & 186.6 & 147.5 & 100.0 & - \\
Average women / men & 67.2 & 69.5 & 93.5 & 66.1 & 72.4 & 78.9 & 81.7 & 79.1 & 88.8 & 76.0 \\
Median women / men & 65.0 & 78.1 & 90.9 & 81.0 & 63.2 & 80.0 & 83.3 & 85.3 & 100.0 & 75.0 \\
Percentile 10 women / men & 83.3 & 81.2 & 125.0 & 100.0 & 90.5 & 96.7 & 100.0 & 69.4 & 66.7 & 66.7 \\
Percentile 90 women / men & 57.1 & 60.9 & 83.3 & 62.5 & 77.8 & 87.5 & 80.0 & 75.0 & 84.6 & 78.1 \\
Perc. 90 / Perc. 10 for men & 11.7 & 11.5 & 7.5 & 11.0 & 5.6 & 5.5 & 3.5 & 2.8 & 4.3 & 5.3 \\
Perc. 90 / Perc. 10 for women & 8.0 & 8.6 & 5.0 & 6.9 & 4.8 & 5.0 & 2.8 & 3.0 & 5.5 & 6.3 \\
\hline \multicolumn{1}{c}{ 2016 } & $\mathrm{A}$ & $\mathrm{B}$ & $\mathrm{C}$ & $\mathrm{D}$ & $\mathrm{E}$ & $\mathrm{F}$ & $\mathrm{G}$ & $\mathrm{H}$ & $\mathrm{I}$ & Total \\
\hline \% men & 3.2 & 3.6 & 2.8 & 6.5 & 2.2 & 7.2 & 26.3 & 30.8 & 17.4 & 100.0 \\
\% women & 2.3 & 3.6 & 1.4 & 15.1 & 0.9 & 5.2 & 14.4 & 28.1 & 29.0 & 100.0 \\
\% women in the category & 38.3 & 46.5 & 29.6 & 67.0 & 27.4 & 39.0 & 32.5 & 44.5 & 59.5 & 46.8 \\
Ratio (average income of I = 100) & 652.3 & 633.9 & 448.4 & 383.8 & 296.2 & 267.0 & 186.9 & 147.6 & 100.0 & - \\
Average women / men & 68.0 & 79.2 & 82.8 & 66.3 & 74.9 & 86.5 & 86.1 & 82.7 & 90.5 & 79.1 \\
Median women / men & 60.0 & 75.0 & 85.7 & 71.4 & 81.0 & 83.3 & 80.0 & 83.3 & 100.0 & 78.6 \\
Percentile 10 women / men & 70.0 & 93.3 & 92.3 & 88.0 & 81.8 & 100.0 & 100.0 & 90.9 & 100.0 & 62.5 \\
Percentile 90 women / men & 60.0 & 71.4 & 85.7 & 58.0 & 80.0 & 80.0 & 86.2 & 77.3 & 86.7 & 75.0 \\
Perc. 90 / Perc. 10 for men & 7.5 & 9.3 & 5.4 & 10.0 & 4.5 & 5.7 & 3.3 & 2.5 & 5.0 & 5.0 \\
Perc. 90 / Perc. 10 for women & 6.4 & 7.1 & 5.0 & 6.6 & 4.4 & 4.5 & 2.8 & 2.1 & 4.3 & 6.0 \\
\hline
\end{tabular}

Source: IBGE - PNADC. Prepared by the authors.

The deep wage inequality in Brazil can also be noticed through the difference between the average income of each category in relation to the average income of category I. For example, category A has an average income that is $695.5 \%$ higher than the average income of category I in 2014. Table 6 shows that the same pattern prevails in 2016, after the Brazilian recession. 
Table 6 also shows the wage inequality between men and women. Considering all activities, the average women's income corresponded to $76.0 \%$ of men's income in 2014, improving to $79.1 \%$ in 2016 . Considering that in the period of 2014 to 2016 Brazil was under a deep recession and that men's unemployment rate increased faster than women's rate, probably the lower difference between men and women's income occurs because men's income deteriorates more than women's income, as already discussed.

Men's higher income occurs in all categories analysed. Category A is the category with the highest difference between men and women, where women's average income corresponds to only $67.2 \%$ of men's average income in 2014 and $68 \%$ in 2016 . This means that in the category that corresponds to better occupations, men receive much higher salaries than women do. On the other extreme, in category I women's income is closer to men's income, although it is still lower. In this category, the average women's income in relation to men improved in 2016, when women received on average $90.5 \%$ of men's average income. The participation of women in this category is higher than the participation of men and corresponds to $28.5 \%$ of working women. Therefore, the income difference is lower in activities that require less education and that pay lower wages. It is important to highlight that, in this case, probably women and men's income are closer because both receive very low wages.

When we analyse the tenth percentile and the ninety percentile, we also see that, on average, women's income is much lower than men's income, especially in the tenth percentile, where women earn only $66.7 \%$ of men's income in 2014 (78.1\% in the case of the ninety percentile). When we analyse for each category, women's income is closer to men's income in the tenth percentile, especially in intermediate and lower categories. The reason for this is that wages are low in all these categories, for both men and women.

With the recession, women's income in relation to men's income deteriorated in both percentile 10 and percentile 90 , but each category presented a different pattern. In category $D$, which is an intermediate category and the one with the highest participation of women, the average income of women was $66.1 \%$ of men's income in 2014 and stayed roughly the same in 2016 (66.3\%). However, for the case of percentile 10 and percentile 90, in both cases, women's income in relation to men deteriorated. In category B, which is a category with relative high income and which requires higher levels of education, the participation of women in 2014 was $52.7 \%$, decreasing to $46.5 \%$ in 2016 . Women's income was also lower than men's income, but the difference reduced in 2016, probably due to a reduction in men's income. The difference between percentile 90 in relation to 10 for men and women also reduced. 
In short, this analysis shows that the income inequality in Brazil is very high, both between the categories and between men and women. A characteristic of Brazil is that women's income is much lower than men's income, being closer for categories with lower wages and lower levels of education. The recession decreased the difference between men's and women's income especially because men's income deteriorated in the period.

Table 6 also shows that segregation exists in the different categories presented, with a higher proportion of men in most of them than the total proportion of men. This horizontal segregation is also reinforced by a possible discrimination and vertical segregation, considering that in the same category women receive a much lower income compared to men and are in lower hierarchical positions compared to men.

One method to measure segregation is the Duncan dissimilarity index (Duncan \& Duncan, 1955) that compares the distribution of men and women for all occupations (Hermeto, 1997). The index is calculated using the following formula:

$$
I D=\frac{1}{2} \sum_{i}\left|\frac{M_{i}}{M}-\frac{W_{i}}{W}\right|
$$

in which $\mathrm{W}_{\mathrm{i}}$ is the number of women in the occupational group, $\mathrm{W}$ is the total number of employed women, $M_{i}$ is the number of men in the occupational group and $M$ is the total number of employed men. If ID $=0$, there is complete equality; if $I D=1$, there is complete dissimilarity. ${ }^{13}$

The interpretation of the Duncan dissimilarity index is that it provides the proportion of employed workers that should change occupations in a way to make the sex ratio of each occupation to be equal to the sex ratio of the labour force (Hermeto, 1997, p.27). Accordingly, higher index values suggest higher segregation in the labour market. However, the index is highly affected by the occupational classification and by the participation rate. According to Emerek et al. (2003), the index can suggest a low segregation for some countries because the female participation rate is very low, while for other countries it suggests a high segregation because the female participation rate is high. According to the authors, this is because the gender discrimination and segregation occur in every country and they become more explicit when there are more women engaged in the labour market.

Table 7 shows the estimation of the Duncan dissimilarity index for the Brazilian labour market in 2014 and 2016, taking into account the nine categories analysed in this section. The results show that the dissimilarity index had a slight increase during the recession.

\footnotetext{
13 Other indexes are Moir and Selby-Smith (MSS) and Karmel and MacLachlan (IP). ID, MSS and IP go in the same direction and they depend on the occupational structure. The ID is the most common index used in the literature and this is why it is calculated in this article.
} 
Table 7. Duncan dissimilarity index. Brazil: 2014, 2016.

\begin{tabular}{ccccccc}
\hline & & 2014 Q3 & & & 2016 Q3 & \\
& \% men & \% women & Abs(M-W) & \% men & \%omen & Abs(M-W) \\
\hline A & 3.0 & 2.0 & 1.0 & 3.2 & 2.3 & 0.9 \\
B & 3.8 & 4.9 & 1.1 & 3.6 & 3.6 & 0.0 \\
C & 2.5 & 1.1 & 1.4 & 2.8 & 1.4 & 1.5 \\
D & 5.9 & 13.2 & 7.3 & 6.5 & 15.1 & 8.6 \\
E & 3.2 & 1.2 & 2.0 & 2.2 & 0.9 & 1.2 \\
F & 7.3 & 5.4 & 1.9 & 7.2 & 5.2 & 2.0 \\
G & 27.1 & 14.6 & 12.5 & 26.3 & 14.4 & 11.9 \\
H & 30.1 & 29.0 & 1.1 & 30.8 & 28.1 & 2.7 \\
I & 17.1 & 28.5 & 11.4 & 17.4 & 29.0 & 11.6 \\
Total & 100.0 & 100.0 & 39.7 & 100.0 & 100.0 & 40.5 \\
\hline ID & \multicolumn{7}{c}{} \\
\hline
\end{tabular}

Source: IBGE - PNADC. Prepared by the authors.

Note: $\operatorname{Abs}(\mathrm{M}-\mathrm{W})$ is the absolute difference between the proportion of men and of women in the specific category.

Although the Brazilian index seems to be low (19.8\% in 2014 and $20.2 \%$ in 2016), this pattern is similar to other countries that have lower participation rate for women. The low Brazilian dissimilarity index may be a result of a low women's participation rate, and it does not necessarily mean a better situation for women in general. ${ }^{14}$ Women's participation increased from 2014 to 2016 and the same occurs to the dissimilarity index, making more explicit the gender segregation and possible discrimination that prevails in this economy.

Tables 6 and 7 show that, while segregation increased between 2014 and 2016, the ratio between women's average income relative to men's average income decreased. As segregation is part of the explanation for inequality, one would expect that its increase would lead to an increase in sex wage inequality. This did not occur because discrimination (difference between men's and women's average incomes) and vertical segregation reduced in each category, except for category $\mathrm{C}$, and because the categories which explain most of the increase in the ID rate, such as category $\mathrm{H}$, are categories in which women's average income is relatively closer to men's average income. It is also important to highlight that the decrease in wage inequality in this context does not seem to reflect a lower discrimination, but rather the reduction in men's income levels due to the Brazilian recession. On the other hand, the smaller gap between the women's participation in categories A and B and their participation in the total of the labour force helped to decrease the wage inequality between men and women, as these are categories of high income levels, despite the fact that they are also categories of high discrimination in terms of income levels.

\footnotetext{
${ }^{14}$ Still, in case this low ID index occurs simultaneously to a relatively higher sex wage inequality, it may indicate that discrimination within the categories plays a relatively more important role in determining such inequality.
} 


\section{Conclusions}

The Brazilian recession of 2015 and 2016 had a negative impact on its labour market and reverted the improvements that took place during the period of higher economic growth with social inclusion, which were particularly important for women. The lower economic activity did not decrease women's participation rates, helping to avoid losses in the household income, but this led to an even higher unemployment rate as the number of employed women decreased. At the same time, the differences between men and women's wages reduced, which resulted from the deterioration of men's income and not from an improvement in women's income. In this sense, the precarious situation for most women still prevails in the Brazilian labour market, which is a reflex of discrimination and segregation.

The segregation and discrimination can be seen through the analysis of each group of workers, when there is a higher participation of men in more complex categories, classified according to the level of education and the levels of remuneration, while there are more women in relation to men in categories that require low education level and have lower wages. This analysis is complemented by the Duncan dissimilarity index that shows that in the case of Brazil, when the participation rate of women increased, the dissimilarity also increased, making more explicit the sex discrimination and segregation that prevails in this economy. Thus, if the economic activity improves and the same pattern of women's participation and segregation in the labour market persist, probably wage inequality will also increase as well as wage differences by sex, especially in case the public policies that improved the working conditions for women are weaker than they were in the period of economic growth with social inclusion.

\section{References}

Abramo, L. (2004). Perspectiva de gênero e raça nas políticas públicas. Mercado de Trabalho - Conjuntura e Análise [Boletim do IPEA], (25), 17-21. http://www.clam.org.br/bibliotecadigital/uploads/publicacoes/675 781 abramo.pdf

Arriagada, I. (2006). Transformações sociais e demográficas das famílias latino-americanas. In J. M. Domingues \& M. Maneiro (Orgs.), América Latina hoje: Conceitos e interpretações. Rio de Janeiro: Civilização Brasileira.

Baltar, C. T., \& Rolim, L. N. (2018). Desigualdade e vulnerabilidade no mundo do trabalho. In J. D. Krein, D. M. Gimenez, \& A. L. dos Santos (Orgs.), Dimensões críticas da reforma trabalhista no Brasil (pp. 243-274). Campinas: Curt Nimuendajú. https://www.eco.unicamp.br/images/arquivos/LIVRODimensoes-Criticas-da-ReformaTrabalhista-no-Brasil.pdf

Baltar, P. E. A., \& Leone, E. T. (2015). Perspectivas para o mercado de trabalho após o crescimento com inclusão social. Estudos Avançados, 29(85), 53-67. https://doi.org/10.1590/S0103-40142015008500005 
Bandeira, L. M., \& Preturlan, R. B. (2016). As pesquisas sobre uso do tempo e a promoção da igualdade de gênero no Brasil. In N. Fontoura \& C. Araujo (Orgs.), Uso do tempo e gênero (pp. 43-59). Rio de Janeiro: UERJ.

http://www.onumulheres.org.br/wp-content/uploads/2016/04/uso do tempo e genero.pdf

Beltrão, K. I., \& Alves, J. E. D. (2009). A reversão do hiato de gênero na educação brasileira no século XX. Cadernos de Pesquisa, 39(136), 125-156.

https://www.scielo.br/pdf/cp/v39n136/a0739136.pdf

Benería, L., Beik, G., \& Floro, M. S. (2010). Gender, development, and globalization: Economics as if all people mattered (2nd ed.). Routledge.

https://doi.org/10.1080/02255189.2016.1146130

Biavaschi, M. B. (2017). Os direitos das trabalhadoras domésticas e as dificuldades de implementação no Brasil: contradições e tensões sociais. In E. Leone, J. D. Krein, \& M. Teixeira (Orgs.), Mundo do trabalho das mulheres: Ampliar direitos e promover a igualdade (pp. 243-263). Campinas: Unicamp.IE.Cesit. https://www.cesit.net.br/wp-content/uploads/2017/12/Mundotrabalho-mulheres-web.livro -1.pdf

Bruschini, C. (2000). Gênero e trabalho no Brasil: novas conquistas ou persistência da discriminação? In M. I. B. Rocha (Org.), Trabalho e gênero: mudanças, permanências e desafios. São Paulo: Editora 34.

Corseuil, C. H., \& Foguel, M. N. (2002). Uma sugestão de deflatores para rendas obtidas a partir de algumas pesquisas domiciliares do IBGE. [Texto para Discussão, n. 897], IPEA, Rio de Janeiro. https://www.ipea.gov.br/portal/images/stories/PDFs/TDs/td 0897.pdf

Dedecca, C. S. (2004). Tempo, trabalho e gênero. In A. A. Costa et al. (Orgs.), Reconfiguração das relações de gênero no trabalho (pp. 21-52). São Paulo: CUT. https://library.fes.de/pdffiles/bueros/brasilien/05632.pdf

Duncan, O. D., \& Duncan, B. (1955). A methodological analysis of segregation indexes. American Sociological Review, 20(2), 210-217. http://www.jstor.org/stable/2088328

Emerek, R., Figueiredo, H., González, P., Gonäs, L., \& Rubery, J. (2003) Indicators on gender segregation. [DP 2003-2], Centro de Estudos de Economia Industrial, do Trabalho e da Empresa (CETE), Universidade do Porto. https://core.ac.uk/download/pdf/6379134.pdf

England, P. (2010). The gender revolution: uneven and stalled. Gender \& Society, 24(2), 149166. http://www.jstor.org/stable/27809263

Gibb, L. S. F., \& Oliveira, A. L. M. (2015). A desigualdade na distribuição do trabalho total no Brasil: a quem favorece? Revista Pesquisa \& Debate, 26(2), 87-104. https://revistas.pucsp.br/rpe/article/view/22683/17599

Guedes, M. de C., \& Alves, J. E. D. (2004). A população feminina no mercado de trabalho entre 1970-2000: particularidades do grupo com nível universitário. Anais do XIV Encontro Nacional de Estudos de População, ABEP, Caxambu-MG, Brasil, 14. http://www.abep.org.br/publicacoes/index.php/anais/article/viewFile/1307/1271

Hermeto, A. M. (1997). A segregação ocupacional por sexo no Brasil. [Dissertação de Mestrado], Universidade Federal de Minas Gerais, Brasil. https://repositorio.ufmg.br/handle/1843/MCCR-76AR2B 
Hirata, H. (2017). O que mudou e o que permanece no panorama da desigualdade entre homens e mulheres? Divisão sexual do trabalho e relações de gênero numa perspectiva comparada. In E. Leone, J. D. Krein, \& M. Teixeira (Orgs.), Mundo do trabalho das mulheres: Ampliar direitos e promover a igualdade (pp. 143-173). Campinas: Unicamp.IE.Cesit. https://www.cesit.net.br/wp-content/uploads/2017/12/Mundo-trabalho-mulheres-web.livro -1.pdf

Hoffmann, R.; de Jesus, J. G., \& de Almeida, S. S. P. (2018). A distribuição da renda no Brasil conforme a PNAD: 1995-2017. [Texto para Discussão n. 45], Instituto de Estudos de Política Econômica / Casa das Garças (IEPE/CdG), Rio de Janeiro, Brasil. http://iepecdg.com.br/wpcontent/uploads/2018/08/PNAD9517E.pdf

Leone, E., \& Baltar, P. (2006). Mercado de trabalho metropolitano: Gênero e diferenças de rendimento, 1992-2002. Gênero, 7(1), 37-58.

https://periodicos.uff.br/revistagenero/article/view/31101/18190

Leone, E. T. (2020). Women's participation in the Brazilian labour market in the context of economic growth with income distribution (2004-2013). Panoeconomicus, 67(3), 433-447. http://dx.doi.org/10.2298/PAN2003433T

Leone, E. T. (2017). Os impactos do crescimento econômico com inclusão social na participação das mulheres no mercado de trabalho. In E. Leone, J. D. Krein, \& M. Teixeira (Orgs.), Mundo do trabalho das mulheres: Ampliar direitos e promover a igualdade (pp. 1337). São Paulo: Secretaria de Políticas do Trabalho e Autonomia Econômica das Mulheres; Campinas: Unicamp.IE.Cesit. https://www.cesit.net.br/wp-content/uploads/2017/12/Mundotrabalho-mulheres-web.livro -1.pdf

Mariano, S. A., \& Carloto, C. M. (2009). Gênero e combate à pobreza: Programa Bolsa Família. Estudos Feministas, 17(3), 901-908. https://doi.org/10.1590/S0104-026X2009000300018

Montali, L. (2017). Mudanças na família, no mercado de trabalho e nos arranjos familiares. In E. Leone, J. D. Krein, \& M. Teixeira (Orgs.), Mundo do trabalho das mulheres: Ampliar direitos e promover a igualdade (pp. 39-66). São Paulo: Secretaria de Políticas do Trabalho e Autonomia Econômica das Mulheres; Campinas: Unicamp.IE.Cesit. https://www.cesit.net.br/wpcontent/uploads/2017/12/Mundo-trabalho-mulheres-web.livro -1.pdf

Oliveira, A. M. H. C. (1998). Indicadores de segregação ocupacional por sexo no Brasil. Anais do XI Encontro Nacional de Estudos Populacionais, ABEP, Caxambu-MG, Brasil, 11, 24992526. http://www.abep.org.br/publicacoes/index.php/anais/article/view/939/904

ONU Mulheres (2016). Mais igualdade para as mulheres brasileiras: caminhos de transformação econômica e social. [Encarte baseado no Relatório "O progresso das mulheres no mundo do trabalho"]. Brasília: ONU Mulheres. http://www.onumulheres.org.br/wpcontent/uploads/2016/05/encarte-Mais-iqualdade-para-as-mulheres-brasileiras site v2.pdf

Pinheiro, L. S. (2016). Determinantes da alocação do tempo em trabalho reprodutivo: uma revisão sobre os achados em pesquisas nacionais e internacionais. In N. Fontoura \& C. Araújo (Orgs.), Uso do tempo e gênero (pp. 61-99). Rio de Janeiro: UERJ.

http://www.onumulheres.org.br/wp-content/uploads/2016/04/uso do tempo e genero.pdf

Portilho, L. (2020). Mercado de trabalho e as diferenças de gênero: o caso das ocupações de nível superior no Brasil (2004-2013). [Tese de Doutorado], Instituto de Economia, Unicamp. http://repositorio.unicamp.br/jspui/bitstream/REPOSIP/343529/1/Silva LucianaPortilhoDa D.pdf 
Ribeiro, R., \& Araujo, G. S. (2016). Occupational segregation in the labour market according to skin colour and level of schooling in contemporary Brazil. Nova Economia, 26(1), 147-177. https://doi.org/10.1590/0103-6351/2652

Santos, A. L. dos, \& Gimenez, D. M. (2015). Inserção dos jovens no mercado de trabalho. Estudos Avançados, 29(85), 153-168. https://doi.org/10.1590/S0103-40142015008500011

Teixeira, M. O. (2013). O mercado de trabalho reitera relações desiguais que se constroem no âmbito das relações econômicas e sociais. In Fundação Perseu Abramo \& Fundação Friedrich Ebert (Orgs.), Classes? Que classes? (pp. 105-123). São Paulo: Editora FPA.

https://library.fes.de/pdf-files/bueros/brasilien/10597.pdf

Teixeira, M. O. (2017). O que gera e perpetua a segregação, a discriminação e as desigualdades salariais. In E. Leone, J. D. Krein, \& M. Teixeira (Orgs.), Mundo do trabalho das mulheres: Ampliar direitos e promover a igualdade (pp. 67-90). São Paulo: Secretaria de Políticas do Trabalho e Autonomia Econômica das Mulheres; Campinas: Unicamp.IE.Cesit. https://www.cesit.net.br/wp-content/uploads/2017/12/Mundo-trabalho-mulheresweb.livro -1.pdf

Teixeira, M. O. (2019). Os efeitos econômicos da reforma trabalhista. In J. D. Krein, R. V. de Oliveira, \& V. A. Filgueiras (Orgs.), Reforma trabalhista no Brasil: promessas e realidade. Campinas: Curt Nimuendajú. https://www.cesit.net.br/wp-content/uploads/2019/09/LivroREMIR-v-site.pdf

Received on 20 July 2020.

Approved on 29 August 2020. 